\title{
УДК 343.541
}

DOI https://doi.org/10.32847//n.2021.13.2.11

\section{Логвинський Г.В. \\ аспірант кафедри кримінального права Національний університет «Одеська юридична академія»}

\section{СУБ'ЄКТ ПОСЯГАННЯ НА ЗАХИСНИКА ЧИ ПРЕДСТАВНИКА ОСОБИ}

3 огляду на тему даного дослідження, необхідним є дослідити суб'єктивні ознаки посягання на захисника чи представника особи. Згідно 3 теорією кримінального права до таких ознак належать ознаки суб'єкта посягання на захисника чи представника особи та суб'єктивної сторони.

Говорячи про суб'єкта злочину як про елемент складу злочину, на практиці нерідко отожнюють поняття «суб'єКт злочину» і «особа злочинця».

Про суб'єкт кримінального правопорушення слід говорити як про елемент складу кримінального правопорушення, який характеризується сукупністю обов'язкових ознак, а також в певних випадках - факультативних ознак, визначених складом конкретної кримінально-правової норми (спеціальний суб'єкт). Таким чином, під суб'єктом кримінального правопорушення розуміється не людина і не особа, а юридична умовність, тобто сукупність ознак, які визначають правовий, вікової і психічний статус особи, відповідальної за вчинення злочину.

Суб’єкт - фізична осудна особа, якій на момент вчинення злочину виповнилося 16 . Понижений вік - ч. 2 і 3 ст. 398, ст. 400 КК.

Злочини, що посягають на життя та здоров'я захисника чи представника особи у зв'язку з діяльністю, пов'язаною з наданням правової допомоги, можуть бути вчинені винятково загальними суб' єктами [1].

Суб'єктом злочину, передбаченого ч. 1 ст. 398, а також умисного заподіяння потерпілому легких тілесних ушкоджень (ч. 2 ст. 398) може бути осудна особа, яка досягла 16-річного віку, а суб'єктом заподіяння умисного серед- ньої тяжкості (ч. 2 ст. 398) і тяжкого тілесного ушкодження (ч. 3 ст. 398) - 14-річного віку. Суб'єкт злочину, передбаченого ст. 400 КК України є особа, що досягла 14-річного віку. Якщо даний злочин вчинила службова особа при перевищенні влади або службових повноважень, іiі діяння слід кваліфікувати за сукупністю злочинів - за ч. 3 ст. 365 та ст. 379 (ст. 400) КК України [2, с. 65].

Л.М. Палюх зазначає, що у всіх основних складах кримінальних правопорушень цієї групи суб'єкт - загальний. Розглянуто проблеми, що стосуються установлення в КК України віку, з якого може наставати кримінальна відповідальність за правопорушення, що посягають на особисті блага спеціальних потерпілих (у розділі XVIII Особливої частини КК України - передбачені ст. ст. 377, 378, 379, 398, 399, 400 КК України) [3, с. 17].

3 техніко-юридичної точки зору мінімальний вік суб'єкта злочину регламентований в КК України двояко: як загальна норма щодо всіх видів складів злочинів і поряд із загальною як додаткова спеціальна норма по окремим видам складів злочинів. 16-річний вік, 3 досягненням якого особа може підлягати кримінальній відповідальності за вчинення складів злочинів загальним і спеціальним суб' єктом, в теорії кримінального права прийнято називати загальним мінімальним віком суб'єкта злочину, а 14-річний вік, з досягненням якого особа може підлягати кримінальній відповідальності за вчинення окремих складів злочинів - зниженим мінімальним віком суб'єкта злочину [4, с. 71].

3 огляду на вище викладене, можна назвати наступні аргументи проти використання 
диференційованого підходу до встановлення мінімального віку суб'єкта злочину. По-перше, міжнародні нормативно-правові акти не передбачають обов'язковість використання диференційованого підходу до встановлення мінімального віку суб'єкта злочину. По-друге, диференційований підхід до встановлення мінімального віку суб'єкта злочину в залежності від певних видів складів злочинів породжує проблему щодо формування переліку складів злочинів, кримінальна відповідальність за які може наступати з зниженого мінімального віку суб' єкта злочину. По-третє, вікова періодизація психічного розвитку $\epsilon$ умовним і не визначає чітких меж вікових періодів. Тому і не варто класти їі в основу диференційованого підходу. По-четверте, диференційований підхід не вирішує питання «вікової незрілості» [5, с. 21]. На нашу думку, слід підтримати підхід тих учених, які пропонують встановлення єдиного мінімального віку суб'єкта злочину, тому що це дозволить враховувати при кваліфікації діяння в кожному конкретному випадку індивідуальний розвиток особи кримінального правопорушника, а не загальний типовий розвиток осіб у певному віку, а також вирішити питання про «вікову незрілість».

Видається, що законодавець сам заплутався, використовуючи свій систематизований підхід щодо виділення складів злочинів, за вчинення яких кримінальна відповідальність може наставати за досягнення 14 років. Адже в 2015 р КК України доповнено такими статтями: ст. 345-1 «Погроза або насильство щодо журналіста», ст. 347-1 «Умисне знищення або пошкодження майна журналіста», ст. 348-1 «Посягання на життя журналіста», ст. 349-1 «Захоплення журналіста як заручника». Однак в ч. 2 ст. 22 КК України ніяких змін не внесено, що в черговий раз свідчить про відсутність системного підходу з боку законодавця. У зв'язку з цим складається абсурдна ситуація: за умисне вбивство (ст.ст. 115-117 КК України), посягання на життя державного чи громадського діяча, працівника правоохоронного органу, члена громадського формування з охорони громадського порядку i державного кордону або військовослужбовця, судді, народного засідателя чи присяжного у зв'язку з їх діяльністю, пов'язаною із здійсненням правосуддя, захисника чи представника особи у 19 зв'язку 3 діяльністю, пов'язаною з наданням правової допомоги, представника іноземної держави (статті. 112, 348, 379, 400, 443 КК України) особа підлягає кримінальній відповідальності $з$ досягненням 14 років, а за посягання на життя журналіста (ст. 348-1 КК України) з 16 років [5, с. 21$]$.

Найбільш складним і проблемним $\epsilon$ питання про кримінальну відповідальність юридичних осіб. 31 вересня 2014 вступив в силу Закон України від 23 травня 2013 р. «Про внесення змін до деяких законодавчих актів України у зв'язку з виконанням Плану дій щодо лібералізації Свропейським Союзом візового режиму для України щодо відповідальності юридичних осіб». Цим же Законом Загальну частину КК України доповнено розділом XIV-1 «Заходи кримінально-правового характеру щодо юридичних осіб». Питання про юридичних осіб як суб'єктів кримінальної відповідальності не відрізняється особливою новизною, але воно настільки не «вписується» в доктрину кримінального права, що сьогодні важко повірити, що теорія стала реальністю [6, с. 128].

Варто наголосити, що з 27 держав $\mathrm{CC} \mathrm{у}$ законодавстві більше половини 3 них передбачено можливість притягнення юридичних осіб до кримінальної відповідальності. Так, юридична особа підлягає кримінальній відповідальності у таких європейських державах: а) що входять до складу СС (Королівство Бельгія, Сполучене Королівство Великобританії і Північної Ірландії, Угорська Республіка, Королівство Данія, Республіка Ірландія, Республіка Мальта, Королівство Нідерландів, Республіка Польща, Румунія, Республіка Словенія, Фінляндська Республіка, Французька Республіка, Королівство Швеція, Естонська 
Республіка); б) що не входять до складу СС (Республіка Албанія, Республіка Ісландія, Республіка Македонія, Республіка Молдова, Королівство Норвегія, Республіка Хорватія, Республіка Чорногорія); в) у яких передбачена квазікримінальна, тобто адміністративно-кримінальна відповідальність юридичних осіб (Австрійська Республіка, Італійська Республіка, Королівство Іспанія, Федеративна Республіка Німеччина) [7, с. 72].

В.К. Грищук, О.Ф. Пасєка розглядають шляхи вирішення проблеми запровадження кримінальної відповідальності юридичних осіб в Україні [7, с. 275]. Перший шлях, на думку вчених, загальновідомий. Серед колишніх радянських учених його сформулювала С.Г. Келіна, яка у процесі підготовки нового КК Російської Федерації розробила та запропонувала самостійну законодавчу конструкцію розділу КК щодо кримінальної відповідальності юридичних осіб. Теоретична модель кримінально-правових норм de lege ferenda, розроблених С.Г. Келіною, практично повністю була реалізована на законотворчому рівні (за винятком статті «Загальні положення») у главі 16 проекту нового КК Російської Федерації (Загальна частина) 1994 р. 3 деякими редакційними уточненнями. Однак законодавець у підсумку не сприйняв у новому Кримінальному кодексі Російської Федерації 1996 р. ідею про кримінальну відповідальність юридичних осіб. Другий шлях зводиться до розмежування понять суб'єкта злочину та суб'єкта кримінальної відповідальності. За такого підходу суб'єктом злочину пропонується визнавати, як і раніше, тільки фізичну, осудну особу, що досягла певного віку, і одночасно, не видозмінюючи кримінального законодавства, визнати носієм (суб'єктом) кримінальної відповідальності юридичну особу [7, с. 275].

Введення інституту кримінальної відповідальності юридичних осіб впливає на розуміння змісту ряду інших правових інститутів. Ми вже не замислюємося над тим, наскільки доцільно, необхідно і правильно вводити інститут кримінальної відповідальності юридичних осіб. Швидше за все тут вже нічого не можна змінити. Але це положення не дає відповідь на питання про правову природу заходів кримінально-правового характеру, які мають застосовуватися до юридичних осіб. Ми частково відмовляємося від категорії «покарання», повертаємося в 20-ті роки до прообразу заходів соціального захисту. Ці заходи, очевидно, будуть існувати паралельно 3 покаранням як його різновид. Наступне питання стосується основоположного доктринального положення про склад злочину. Яким чином юридичні особи будуть «вписуватися» у вчення про суб'єкт злочину, у вчення про вину, співучасть, про принципи призначення покарання і в деякі інші інститути Загальної частини кримінального права [6, с. 128].

Насамперед варто зазначити, що запровадження кримінальної відповідальності юридичних осіб у вітчизняне законодавство справді викликає значну кількість проблем, однак їх, на нашу думку, можна подолати. Більше того, такі спроби вже мали місце в історії незалежної України. Відомий проект КК України 1993 р., внесений Комісією ВР України з питань правопорядку та боротьби iз злочинністю, передбачав можливість кримінальної відповідальності юридичних осіб. Спробою запровадження кримінальної відповідальності юридичних осіб, на виконання взятих Україною на себе міжнародних зобов'язань, був Закон України «Про відповідальність юридичних осіб за вчинення корупційних правопорушень» від 11 червня 2009 р. Однак, проаналізувавши зміст цього Закону, вчені підтримуєть позицію О. Шамари, який зазначив, що прийняття такого закону зумовило його невідповідність Загальній частині Кримінального кодексу України, що на практиці може призвести до виникнення правових колізій [7, с. 276].

Таким чином, для української кримінально-правової традиції не $є$ характерним те, що, наприклад, у деяких кримінальних законах певних зарубіжних країн прямо в тексті статті 
міститься вказівка на можливість притягнення юридичних осіб до кримінальної відповідальності за вчинення за вчинення певних діянь.

На таку ситуацію вже звертали увагу відомі українські науковці. Так, Є.Л.Стрельцов, А.М.Соловйова та Т.Б. Герелюк, автори монографії під назвою «Об'єкти культурної спадщини в країнах Східної Європи: кримінально-правова охорона» слушно зауважують, що законодавства держав Східної Свропи передбачають різні спеціальні системи кримінальних покарань для юридичних осіб, які часто досить різноманітні. Вивчаючи їх, можна виділити цілий ряд «типових», які найбільш часто зустрічаються [8].

Науковці зазначають, що закріплення відповідальності юридичної особи на рівні окремої частини статті $\epsilon$ обов'язковою умовою. Так, наприклад, у статті 20 КК Литовської Республіки передбачено, що юридична особа несе відповідальність за злочинні діяння тільки в тому випадку, якщо така відповідальність передбачена спеціальною частиною КК [8].

КК Естонії 2002 р. вказує на корпоративну кримінальну відповідальність юридичної особи, яка може підлягати такій відповідальності за незаконні дії, вчинені одним з їі органів чи посадовою особою, якщо злочин був вчинений в інтересах юридичної особи (секція 14 КК) [7, с. 84].

Так, нами проаналізовано кримінальне законодавство країн Балтії і встановлено, що посягання на захисника чи представника особи криміналізовано на рівні спеціальних норм лише у Пенітенціарному кодексі Естонії, про що детально буде зазначено на рівні Розділу 5 цієї роботи. 3 метою більш детального розкриття проблеми суб' єкта посягання на захисника чи представника особи зупинимося на деяких моментах.

У кримінальному законодавстві Естонії також не визначено умов обов'язкового засудження винної фізичної особи. Стаття 5 «Про відповідальність юридичних осіб за кримінальні злочини» зазначає, що кримінальна відповідальність організації базується на вині iï керівника (ст. 5 (1)). Проте у ст. 5 (2) передбачається можливість притягнення юридичної особи до відповідальності й у разі, якщо засудження винної фізичної особи неможливе з тих чи інших причин.

Ураховуючи наявність двох окремих статей (параграфів) у Пенітенціарному Кодексі Естонії, положення яких спрямовані на охорону захисника від посягань, зауважимо що це: $§ 302$ П (Influencing of administration of justice by causing serious health damage), яким встановлено кримінальну відповідальність за вчинення незаконного впливу на здійснення правосуддя шляхом заподіяння серйозної шкоди здоров'ю та $\S 303$ (Influencing of administration of justice), яким встановлено кримінальну відповідальність за здійснення акту насильства проти особи, яка бере участь у здійсненні правосуддя.

Відповідно до ч. $1 \S 302$ Пенітенціарного кодексу Естонії заподіяння серйозної шкоди здоров'ю з метою змусити суддю, народного засідателя, попереднього слідчого, прокурора, законного представника учасників провадження, керуючого при банкрутстві, експерта, перекладача чи інших осіб, які беруть участь у здійсненні правосуддя, діяти всупереч інтересам справедливості або помсти за виконання такою особою своїх обов'язків, карається позбавленням волі на строк від чотирьох до дванадцяти років.

Відповідно до ч. 2 § 302 Пенітенціарного кодексу Естонії те саме діяння, вчинене юридичною особою, карається штрафом. Разом 3 тим, у Пенітенціарному кодексі Естонії наявна окрема норма про відповідальність за вплив на відправлення правосуддя. Так, § 303 такого кодексу має назву - «Вплив на відправлення правосуддя» (Influencing of administration of justice).

Відповідно до ч. 1 § 303 Пенітенціарного кодексу Естонії здійснення акту насильства проти особи, яка бере участь у здійсненні правосуддя, або впливає на таку особу іншим чином, 3 метою змусити іiі діяти всупереч інтересам справедливості або помститися за 
виконання обов'язків такою особою, карається грошовим покаранням або позбавленням волі на термін від одного до п'яти років.

Відповідно до ч. $2 \S 303$ Пенітенціарного кодексу Естонії те саме діяння, вчинене юридичною особою, карається штрафом.

Кримінальна відповідальність юридичних осіб у Македонії була запроваджена у квітні 2004 р. в результаті внесення відповідних змін до КК. Відповідно до ст. 28-а КК Македонії юридичні особи можуть підлягати відповідальності за кримінально карані діяння, якщо вчинення злочину стало результатом дій або неналежного виконання обов'язків службовцем організації чи іншою фізичною особою, яка уповноважена діяти від іiі імені. У Хорватії, згідно зі ст. 3 Закону «Про відповідальність юридичних осіб за кримінальні злочини» 2003 р., організація підлягає відповідальності за злочини, вчинені фізичною особою, яка представляє організацію, якщо вчинення таких дій порушує зобов'язання юридичної особи або в результаті їх вчинення юридична особа отримує незаконний дохід [7, c. 85].

Висновки. Таким чином, у всіх складах кримінальних правопорушень, які встановлюють відповідальність за посягання на захисника (представника) особи, суб'єкт загальний. Аналіз проблем установлення в КК України віку, з якого може наставати кримінальна відповідальність за такі правопорушення показав неточність позиції деяких вчених щодо необхідності підвищення віку суб'єкта 314 років до16 років. На нашу думку, слід підтримати підхід тих учених, які пропонують встановлення єдиного мінімального віку суб'єкта злочину, тому що це дозволить враховувати при кваліфікації діяння в кожному конкретному випадку індивідуальний розвиток особи кримінального правопорушника, а не загальний типовий розвиток осіб у певному віку, а також вирішити питання про «вікову незрілість».

\section{Анотація}

У статті досліджено питання суб’єкта у всіх складах кримінальних правопорушень, які встановлюють відповідальність за посягання на захисника (представника) особи. Обгрунтовано, що у всіх складах кримінальних правопорушень, які встановлюють відповідальність за посягання на захисника (представника) особи, суб'єкт - загальний. Запропоновано аргументи щодо встановлення єдиного мінімального віку суб'єкта злочину, тому що це дозволить враховувати при кваліфікації діяння в кожному конкретному випадку індивідуальний розвиток особи кримінального правопорушника, а не загальний типовий розвиток осіб у певному віку, а також вирішити питання про «вікову незрілість».

Ключові слова: кримінальне право, кримінально-правова характеристика, кримінальне правопорушення, посягання, вбивство, захисник, представник особи.

\section{Lohvynskyi H.V. Subject of attachment to the defendant or representative's representative Summary}

The article examines the issue of the subject in all components of criminal offenses, which establishes liability for encroachment on the defense counsel (representative) of the person. It is substantiated that in all components of criminal offenses that establish liability for encroachment on the defense counsel (representative) of a person, the subject is common. Arguments are proposed to establish a single minimum age of the subject of the crime because it will take into account the qualification of the actin each case, the individual development of the offender, rather than the general typical development of persons at a certain age, and address "age immaturity".

Key words: criminal law, criminal law characteristics, criminal offense, encroachment, murder, defense counsel, representative of a person. 


\section{Список використаних джерел:}

1. Міщук І.П. Кримінально-правова охорона життя та здоров'я захисника чи представника особи [Текст] : автореф. дис. ... канд. юрид. наук : 12.00.08.; Нац. акад. внутр. справ. К., 2012. $20 \mathrm{c}$.

2. Злочини проти правосуддя: навч. посіб. за заг. ред. проф. В.І. Борисова, проф. B.I. Тютюгіна. Харків: Нац.юрид. акад. України, 2011. 155 с.

3. Палюх Л.M. Автореферат. URL: http:/dspace.univd.edu.ua/xmlui/bitstream/ handle/123456789/10669/aref_Paliukh_2021.pdf?sequence=1\&isAllowed=y (дата звернення 22.03.2020).

4. Кримінальний кодекс України. Науково-практичний коментар : у 2 т. / за заг. ред. В. Я. Тація, В. П. Пшонки, В. І. Борисова, В. І. Тютюгіна. - 5-те вид., допов. - Т. 1: Загальна частина / Ю. В. Баулін, В. І. Борисов, В. І. Тютюгін та ін. Харків: Право, 2013. 376 с.

5. Вовк М.3. Уголовно-правовая характеристика возраста, с которого может наступать уголовная ответственность URL: http://www.brsu.by/sites/default/files/crimlow/gotovyj.pdf (дата звернення 22.03.2020).

6. Лихова С. Я. Юридичні особи як суб’єкти кримінальної відповідальності за КК України. URL: https://core.ac.uk/download/pdf/286628479.pdf (дата звернення 22.03.2020).

7. Грищук В.К., Пасєка О.Ф. Кримінальна відповідальність юридичних осіб: порівняльно-правове дослідження: монографія. Львів: Львівський державний університет внутрішніх справ, 2013. 248 с.

8. Стрельцов Є.Л., Соловйова А.М., Герелюк Т.Б. Об'єкти культурної спадщини в країнах Східної Свропи: кримінально-правова охорона: монографія. Київ: Національна академія управління, 2021. 264 с. 